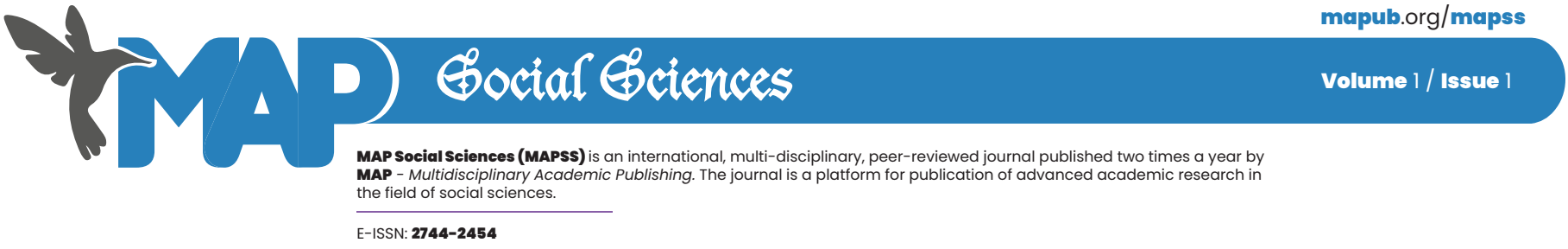

REVIEW PAPER

\title{
TWICE-EXCEPTIONAL, HALF-NOTICED: THE RECOGNITION ISSUES OF GIFTED STUDENTS WITH LEARNING DISABILITIES
}

\author{
Uma Hamzič' (i), Senad Bečirovič² (i) \\ 'International Burch University, Sarajevo, Bosnia and Herzegovina \\ ${ }^{2}$ International Burch University, Sarajevo, Bosnia and Herzegovina
}

Correspondence concerning this article should be addressed to Uma Hamzić, International Burch University, Sarajevo, Bosnia and Herzegovina. E-mail: uma.hamzic@stu.ibu.edu.ba and Senad Bećirović, International Burch University, Sarajevo, Bosnia and Herzegovina. E-mail: senad. becirovic@ibu.edu.ba

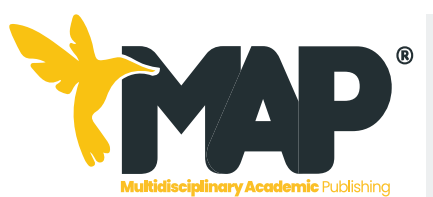

MAP SOCIAL SCIENCES

Volume 1 / Issue

ISSN: 2744-2454/ (c) 2021 The Authors. Published by MAP - Multidisciplinary Academic Publishing.

Article Submitted: 05 August 2021 Article Accepted: 20 August 202 Article Published: 03 September 202

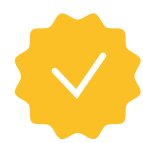

Publisher's Note: MAP stays neutral with regard to jurisdictional claims in published

\section{ABSTRACT}

Gifted children with learning disabilities are known as twice-exceptional. Both the identification and the classification of twice-exceptional children are a matter for practical ingenuity, as these children tend to fall upon extremes of a scale, resulting in either the child with both obvious giftedness and a learning disability or in the child where the giftedness effectively masks the disability. The latter results in a child that tests as average upon surface-level assessments. In this article, a new direction of the identification of twice-exceptional students is proposed in terms of specific learning disabilities, specifically in terms of the latter form of students who go through education undiagnosed. In addition to this direction, we provide a condensed understanding of both giftedness and specific learning disabilities in students, as well as how they interact in twiceexceptionality, and how teachers might best navigate the issue of masking within the classroom.

Keywords: gifted, talented, specific learning disability, twice-exceptional, masking 


\section{Gocial Giences \\ by MAP - Multidisciplinary Academic Publishing}

TWICE-EXCEPTIONAL, HALF-NOTICED: THE RECOGNITION ISSUES OF GIFTED STUDENTS WITH LEARNING DISABILITIES

Uma Hamzić and Senad Bećirović

\section{Introduction}

A crucial form of gifted students is their inherent vulnerability (Bećirović \& Polz, 2021; Lyudmila \& Maria, 2014; Roedell, 1984; Winner, 1996). A gifted student is forced to be somewhat imbalanced, either with poor social and emotional skills (Bećirović $\&$ Polz, 2021) or with an unequal academic ability (Winner, 1996). However, Winner (1996) goes on to describe the latter with the example of a gifted student who is uneven to the point of severe disbalance, upon which this disequilibrium can even be classified as a learning disability.

This idea of a gifted student with a learning disability goes as far back as 1981, but the specific term of twice-exceptionality to denote these specific children only came into use around 2004 (BuicăBelciu \& Popovici, 2014; Coleman et al., 2005). In doing so, the field of education has since delved deep into the issues of classification and identification of twice-exceptional students (Brody \& Mills, 1997; Buică-Belciu \& Popovici, 2014; Flanagan \& Alfonso, 2011; Fletcher et al., 2003; Reis et al., 2014; King, 2005).

This article intends to provide a wider range of understanding of both what it means to be classified as gifted and as specific learning disabled, especially in terms of how to use that knowledge to better understand the classification and assessment of twice-exceptional students. It will also question the practical application of these classifications within the classroom, specifically drawing upon King's (2005) division and the issue of comorbidity (Reis et al., 2014).

\section{Definitions of "Gifted" and "Learning Disabled"}

When it comes to the assessment and incorporation of exceptional students, be it "academically gifted" or "learning disabled", the key problem upon which both the processes of assessment and incorporation hinge is agreeing upon a definition. VanderStoep and Johnston (2009) argue the need for consistency and clarity in operational definitions in terms of allowing researchers and readers to reach a consensus on the data shown, as well as replication studies.

The opposing problem is the lack of knowledge and agreement around definitions outside of the specialized educational community (Bećirović \& Polz, 2021). Educational institutions and communities might resist investing in differentiated instructions or an IEP (Individualized Educational Program) unless a student fits their specific operational definition of gifted or disabled; this can be anything from doing well on tests or assignments to being committed and creative (Matthews \& Foster, 2005). If a teacher uses a biased operational definition, then their assessments and modifications to the curriculum will follow that same bias.

Both the academically gifted and the learning-disabled terms have multiple definitions, which change and evolve with educational progress, and the operational definitions stated below have been chosen either for their recent creation or for their connections to other, cited sources.

The first definition is distinguishing the terms of giftedness and talentness. Bećirović and Polz (2021) allows for this distinction by understanding the inherent contextual and culture differences; where some authors argue that giftedness and talent are true synonyms in the psychological field, others go as far as to say the field of giftedness is so broad that no one theory can accurately cover it (Gojkov, 1999). However, it can be said that the true difference lies within whether the advanced skill in question is due to a natural aptitude or not. If so, this natural aptitude results in a talent, which is also more likely to result in an advanced level of a practical skill. Upon that reasoning, giftedness is more likely to result in an academic skill through exceptional capacity; a student with this ability in an art form or athletic use is therefore talented (Matthews \& Foster, 2005).

When it comes to learning disabilities, there is a division between specific learning disabilities and general learning disabilities. The Learning Disabilities Association of America (2021) defines learning disabilities as "average abilities essential for thinking and/or reasoning (...) distinct from global intellectual deficiency". The key point is that these general learning disabilities do not affect only learning processes; rather, they affect all processes, one of which may be learning. Therefore, for the purpose of this paper, one might say that a general learning disability can be defined as an overall reduction of abilities.

On the other hand, a specific learning disability (or: SLD) is not all-encompassing; it affects a particular aspect within a learning process, which mutates into a difficulty. A more detailed definition 


\section{Gocial Giences \\ by MAP - Multidisciplinary Academic Publishing}

TWICE-EXCEPTIONAL, HALF-NOTICED: THE RECOGNITION ISSUES OF GIFTED STUDENTS WITH LEARNING DISABILITIES

Uma Hamzić and Senad Bećirović

can be found within the Individuals with Disabilities Education Act (2004) and goes as follows:

The term "specific learning disability" means a disorder in 1 or more of the basic psychological processes involved in understanding or in using language, spoken or written, which disorder may manifest itself in the imperfect ability to listen, think, speak, read, write, spell, or do mathematical calculations. Such term includes such conditions as perceptual disabilities, brain injury, minimal brain dysfunction, dyslexia, and developmental aphasia. Such term does not include a learning problem that is primarily the result of visual, hearing, or motor disabilities, of intellectual disabilities, of emotional disturbance, or of environmental, cultural, or economic disadvantage (Specific Learning Disabilities, 2004)

Within this given definition, specific learning disabilities are confined to those processes, primarily psychological, affecting the basic skills and abilities one uses to acquire new information. Due to such categorization, this paper will not concern itself with so-called perceptual disabilities, nor motor. It will also avoid socio-economic processes entirely.

In summary, a gifted student is one who shows an exceptional skill not born of aptitude in an academic field, resulting in an unexpected overachievement. Conversely, a student with a specific learning disability is one who has their basic learning processes affected through psychological means, resulting in an unexpected underachievement (Flanagan \& Alfonso, 2011). It would be a logical assumption to say a twice-exceptional student would be one who shows an unexpected skill level in an academic field, while also having their primary processes of acquiring and understanding new information psychologically hindered, and without the necessity of these academic fields being the same. However, the issue of defining twice-exceptional students is more complicated; defining each of the parts does not equate to the whole.

While the concept of gifted students having learning disabilities can be seen in academic texts as early as 1996 (Winner, 1996), the specific term twice-exceptional being used to denote academically-gifted students with specific learning disabilities was first used by Gallagher (2004). The term has started to gain momentum, with more research being invested into what is being described as "puzzling patterns of behavior" (Buică-Belciu \& Popovici, 2014, p. 519); twice-exceptional students may, for example, have a high level of vocabulary and advanced intellectual skills, but also show a low level of reading and writing abilities. These conundrums make assessments even more difficult, as well as even more essential.

According to Reis et al. (2014) twice-exceptional students have the ability for high or creative achievements in one or more domains, while also manifesting one or more disabilities as defined by locational criteria.

\section{Assessment versus Test}

Before tackling the issue of assessing twice-exceptional students, there is a need to differentiate assessment from test, as well as covering the basic forms of assessment.

Matthews and Foster (2005) differentiate the two by defining a test as a specific instrument, while an assessment is "more comprehensive than any one test and includes several different measures, maybe of which may be tests" (p. 47). A singular test will not be enough to uncover and analyze an intricate mask; we must use several tests of varied purposes to construct a series of measures upon which conclusions may be drawn.

Matthews and Foster (2005, p. 47) also exemplify specific tests for assessing giftedness, such as the Wechsler Intelligence Scale for Children or the Stanford-Binet Intelligence Scale. Meanwhile, their version of an assessment, specifically a "full psychoeducational assessment", will consist of at least one academic achievement test, a measure of learning style and self-concept as defined by Woolfolk (2016), an occasional intelligence test, and a consideration of the child's overall functioning ability in social settings. This last point is important, as a skill disbalance between academic strengths and emotional strengths was one of the symptoms leading to a gifted assessment.

For applied assessment within a classroom time and setting, the issue of masking results in twice-exceptional students being portrayed as underachievers, and not failing students (BuicăBelciu \& Popovici, 2014). However, Brody and Mills (1997) pinpointed three criteria used to identify gifted students with learning disabilities: (a) evidence of an outstanding talent or ability, (b) ev- 


\section{Gocial Giences \\ by MAP - Multidisciplinary Academic Publishing}

TWICE-EXCEPTIONAL, HALF-NOTICED: THE RECOGNITION ISSUES OF GIFTED STUDENTS WITH LEARNING DISABILITIES

Uma Hamzić and Senad Bećirović

idence of a discrepancy between expected and actual achievement, and (c) evidence of a processing deficit.

In order to classify sections (b) and (c), two primary methodologies currently exist to identify possible learning disabilities; problem-solving and intra-individual (Weiss et al., 2016). These approaches are also known as instructional and cognitive. A problem-solving or instructional approach relies on tools, such as a curriculum-based assessment, to provide an already-identified low-achieving student with a corresponding intervention. On the other hand, an intra-individual or cognitive approach focuses on cognitive explanations for the perceived learning difficulty, such as phonological processing (a sub-issue of low reading skills) or working memory.

The differences between the instructional and cognitive approach to LD identification is in the desired result. An instructional approach does not seek to resolve an idea of classification; it only searches for the available tools in each scenario which could be used to support a struggling student. Meanwhile, a cognitive approach focuses on the perceived discrepancy between "intact and deficient abilities" (Kaufman, 2008) as the reason for unexpected underachievement, previously defined as a sole central factor of a learning disability.

However, according to Fletcher et al. (2003), identification of a learning disability relies on the categorical framework upon which it can be further classified into subtypes. Fletcher continues by defining his three main approaches to identifying the correct subtype of LD; achievement subtypes, clinical inferential (or rational) subtypes, and empirically based subtypes.

Finally, King (2005) defines three subtypes of twice-exceptional students; those who identify as gifted with a low-affecting disability, those who are unidentified, and those who identify as both.

The first of these three, those who identify as gifted, have easily-identifiable gifted skill levels while having subtle specific learning disabilities that are easy to mislabel. This group is most likely to achieve grade-level or expected results on testing tools, meaning they are also the most likely to have their specific learning disabilities overlooked (King, 2005).
The second group, those who are unidentified, have their gifted side and their specific learning disability side in constant battle with each other. This results in a perfect mask, with their gifted abilities compensating for their specific learning disabilities, which will be seen as a completely average participation or achievement in the classroom. In reality, these students are functioning at a lower level than their potential might allow, and means the second group is most likely to go completely unidentified. It also means the second group is the most likely to suffer from mild depression later in life (King, 2005).

The third group, those who identify as both, have the highest chances of being given the specific academic and social setting they need in order to achieve their full potential. Because of their high level of ability, any potential learning difficulties can be noticed much more easily. This has the unfortunate side effect of students ultimately being noticed and defined by their disability, and this group will become acutely aware of their perceived failures, resulting in a low self-concept (King, 2005).

\section{Academic and Social Needs}

Yet another scope of twice-exceptional children is what a positive and practical assessment would require. The reasoning behind the theoretical background of both academically gifted and specific learning-disabled students is summarized by Reis et al. (2014): "Identification, when possible, should be conducted by professionals from both disciplines and when at all possible, by those with knowledge about twice exceptionality" (p. 222). Twice-exceptional students have unique needs in all fields, not just academic, and even a correct assessment might not resolve the quality of these needs being met. Bećirović and Polz (2021) state that gifted students need support from all probable fields where a relationship may form, and not just the school itself. Similarly, disabled students will still require accommodation outside of the classroom, even as a student diagnosed with a specific learning disability.

A mainstream model used globally to support students with special education needs is some kind of special treatment or IEP (Bećirović \& Akbarov, 2016; Jones \& Jones, 1995). An Individualized Education Plan has been in active use in education since the 1970s (Pretti-Frontczak and Bricker, 2000) and originated specifically as a methodology of 


\section{Gocial Giences \\ by MAP - Multidisciplinary Academic Publishing}

TWICE-EXCEPTIONAL, HALF-NOTICED: THE RECOGNITION ISSUES OF GIFTED STUDENTS WITH LEARNING DISABILITIES

Uma Hamzić and Senad Bećirović

assessing modifications and accommodations for disabled students; however, it is now a core belief of differentiated education that students work best within individualized settings.

Any programs attempting to allow for specialized educational needs function on three key assumptions; (a) that students need to be challenged to fulfill their potential, (b) that the need for differentiated instruction rises with the level on unexpected ability, negative or otherwise, and (c), that students require coursework on their level and capabilities (Brody, 2001).

The preferred methodology of special education students varies within all countries with any public interest in the field. Where Russian psychology in the 1960s was dominated by the belief of nurture over nature resulting in gifted students, Austrian students were allowed to self-isolate to focus on their skilled fields (Bećirović \& Polz, 2021). This structure can still be seen in Bosnia and Herzegovina, where gifted students are encouraged into competing on the national level with the ability to have unrelated subjects excused; most commonly, the arts.

This structure might also be directly connected to the continued disbalance between educational and social capacities. Winner (2001) states that a rule of gifted ability is unevenness; a student cannot show both verbal and mathematical exceptionality, and when empirically researched, this was confirmed by showing a higher probability of finding an individual with a high mathematical ability with a corresponding low verbal ability as long as they had a high IQ. The same disparity could not be found within low IQ individuals (Winner, 2001).

However, this unevenness may not be limited to academic forms. Bećirović and Polz (2021) show this same disparity between general academic skills and social and emotional skills. It is this disparity which might cause complications in the everyday classroom, as special education students are more likely to be isolated from their peers. While parents and teachers promote differentiation, the same information can be used to mock or ridicule.

Furthermore, because of this insistence on unusual capabilities, gifted students will develop unusually high expectations of their achievements, resulting in a critical fear of failure. Twice-exceptional children, however, will experience failure at much higher levels than a purely gifted child, which will then make the fear of failure into a much higher level as well. This fear can then branch off into performance anxiety, procrastination, aggressiveness, an inherently problematic perfectionist outlook, and impulsive behavior (Ahmetović et al., 2020; King, 2005).

Connected research has linked the selfplaced expectations of twice-exceptional students and a poor self-concept (Want \& Neihart, 2015). Bong and Skaalvik (2003) described the idea of "academic self-concept" as the perception one has about themselves when placed in academic situations, and is developed alongside the internal comparison of the students' abilities in various domains, as well as the external comparison of the student against their peers. This academic self-concept will affect engagement and effort, alongside academic achievement, and research has also shown a positive correlation between academic achievement and peer status in the classroom (Mašić et al., 2020; Plucker \& Stocking, 2001).

Discussion: the Identification of Twice-Exceptional Students

According to Cvetković-Lay and Sekulić-Majurec (1998) some of the following symptoms upon which a gifted diagnosis may be argued has been compiled below:

- above-average reasoning, understanding and acquisition of abstract concepts, generalizing, understanding meaning, and perceiving relationships,

- great intellectual curiosity,

- quick and easy learning,

- wide range of interests,

- (...) ability to work independently,

- (...) demonstrating initiative and originality in cognitive activities, especially in learning and problem solving,

- (...) perfectionist approach to all activities, aversion to error--notices them and develops negative feelings to them,

- (...) preference of adult over peer company.

The same list cannot be compiled for specific learning disorders. Flanagan and Alfonso (2011) argue that for one to understand the meaning of a "specific learning disability" term, one must also 


\section{Gocial Giences \\ by MAP - Multidisciplinary Academic Publishing}

TWICE-EXCEPTIONAL, HALF-NOTICED: THE RECOGNITION ISSUES OF GIFTED STUDENTS WITH LEARNING DISABILITIES

Uma Hamzić and Senad Bećirović

understand the concept of classification in applied psychology. In short, a classification is a hypothetical collection of categorical concepts. In practice, a classification is simply a step closer to the goal of identification, which represents a method of organizing the perceived symptoms within a case to some kind of inherent structure and using said structure to provide a diagnosis.

The classification of specific learning disabilities functions under the expectation that the observer will be able to compile a set of criteria, which can then be used to classify the case to a particular subgroup. Each subgroup will have a unique range of signs. Following this line of reasoning, to try and collect a master-list of symptoms to look for with specific learning disabilities isn't possible; each subgroup under the umbrella classification of specific learning disability will manifest in different ways, and therefore, will have different kinds of symptoms.

However, Flanagan and Alfonso (2011) do share a common theme; as previously mentioned, the "critical aspect of SLD that serves to differentiate it from other academic problems, (...) is unexpected underachievement" (p. 116). Current Individuals with Disabilities Education Act (2004) regulations require some form of assessment showing that a case child does not function on the expected level in any one of the eight fields related to manifesting language (reading, writing, listening, or speaking), as well as proof that the child in question has "received appropriate instruction in regular education settings and (...) data-based documentation of repeated assessments of student progress" (Fletcher et al., 2011, p. 125).

For comprehensive purposes, some of the most frequent symptoms within their specific categories have been compiled. Reading disorders will most often manifest as developmental dyslexia, the mathematical variant of which is dyscalculia; poor handwriting and spelling scores can be a symptom of a writing disorder when not connected to poor motor control; and oral communication may be influenced both by intrapersonal and interpersonal disorders, both of which lead to poor linguistic skills of comprehension and social communication (Flanagan \& Alfonso, 2011).

What this understanding can lead to is a comprehensive approach towards strengths and weaknesses of twice-exceptional students.
Research shows that such students may have above-average abilities within higher-order or abstract thinking skills, as well as a self-awareness of advanced problem-solving and cognitive skills (Bećirović et. al.; Hannah \& Shore, 2008; Munro, 2002). Simultaneously, the same students might have below-average levels in working memory and processing speed, as well as in general socialization and communication skills (Assouline et al., 2010; Wood \& Estrada-Hernández, 2009). Reviewing student records to observe a change in performance or analyzing discrepant scores is one such way for a teacher to attempt identifying a twice-exceptional student (Baldwin et al., 2015).

The primary issue of assessment in terms of definitions is one that has been well-argued, especially with the issue of masking. In the field of twice exceptionality, masking is defined as a compensatory strategy in which a gift may counteract with or minimize the outwardly influence of a disability; or, the opposing reaction, in which a disability counteracts or minimizes a gift (Ottone-Cross et al., 2016; Silverman, 2003). Using the previously-given example of a twice-exceptional student with a high level of vocabulary but a low level of reading skill might focus on their speaking abilities instead. Another, similar example given by Ottone-Cross et al. (2018) gives the example of a student compensating for poor decoding skills with a superior sight word vocabulary.

Through these cases, we can see that masking can influence both the gifted and the disabled aspect of a student. Unless specific assessment is done, neither of these spheres are likely to be recognized, leaving the student without any kind of special education services. It should also be noted that assessment of this is required, not testing, which is a distinction explained in a later section.

Another, crucial issue is one of comorbidity. Feinstein (1970) defined this term as "any distinct additional, clinical entity that has coexisted or that may occur during the clinical course of a patient" (p. 456-457) and is often called upon within the occurrence of two or more different mental disorders. An addiction may follow chemical treatments for anxiety or depression, for example, and this addiction must be treated within its own right as a disorder and not as a side effect.

This paper lists some of the researched and empirically-backed lists of so-called symptoms of 


\section{Gocial Giences \\ by MAP - Multidisciplinary Academic Publishing}

TWICE-EXCEPTIONAL, HALF-NOTICED: THE RECOGNITION ISSUES OF GIFTED STUDENTS WITH LEARNING DISABILITIES

Uma Hamzić and Senad Bećirović

both giftedness and disability. Reis et al. (2014) argue that individuals who have such co-occurring disorders must be considered as "distinct from either syndrome occurring alone" (p. 220). In other words, teachers or educational specialists attempting a twice-exceptional assessment must not simply compare lists of symptoms and try to pick out several that match. We see this mentality echoed in Ottone-Cross et al. (2016) which openly states the need for future research on twice-exceptional students to track specifically such comorbid effects.

Reis et al. (2014) also continue this need by circling back to their own definition, as seen in the introduction section, by emphasizing both masking and comorbidity as a possible reason for individual, comprehensive assessment in both areas, as "one does not preclude the other" (p. 222).

A well-known fact of disability services is that not every special-needs student will be placed into special education. Even if the parents agree and support the assessment, the IEP answers all needs concisely and clearly, and the student admits to the difficulty in question, there is still a chance for the service administrators to label the disability as "reasonable", and therefore, unnecessary for the redirection of allocated resources (Jones \& Jones, 1995). Specific learning disabilities are especially circumnavigated in this situation, both because of the difficulty in assessment and because of the end results when a Response to Intervention is incorporated.

The Centers for Disease Control put forth their estimation of the percentage of children with learning disabilities being anywhere from $5 \%$ to $10 \%$ of the population (Silver, 1989). When it comes to actual studies providing these estimations, it is statistically estimated that $30 \%$ of gifted students have some level of a learning disability, while up to $10 \%$ of high-IQ children will be assessed as having below-average reading skills, going as far as being up to two grades below their expected level (Little, 2001; Winner, 1996).

It is necessary to revisit these statistics. While we have these estimations of how many gifted students have a specific learning disability, it is most specifically the research of King (2005) that shows a foundational need to revisit our estimations of hidden twice-exceptional students.
If we look specifically to the gifted students who perform in an unexpected way outside of their achievements or exceptional potential, then we are more likely to be sensitive towards specific characteristics that would in turn help us to designate disability diagnosis. The place to look for twice-exceptional students is not within the gifted population. Nor is the place to search in the learning-disabled population. To accurately gain information and assessment on what being twice-exceptional entails, we must try to find Williams King's second group of students; those twice-exceptional students that have their gifted side and their specific learning disability side in contrast to each other, and identify as neither.

In this group of students, masking occurs so well that one side compensates for the other. This is in direct contrast with the issue of comorbidity. The crucial understanding of the definition of twice-exceptionality is not that students are likely to exhibit behaviors of both. Rather, it is that the two distinct diagnoses will work together to create a third list of symptoms, which we can then use to classify the individual. Putting this into contrast with how the everyday teacher (with little to no special education training or services) approaches a twice-exceptional analysis, a conclusion can be drawn that Williams King's second group of students is perpetually being overlooked. While studies such as that by Reis (1995) take a closer look into the percentage of twice-exceptional students in primarily gifted or primarily learning-disabled population, new studies are required that assess the possibility for twice-exceptionality in groups of students that test consistently average on a surface level.

In effect, students that mask so well that standardized assessment does not pick up on fluctuations in their expected potential can be argued to be the most balanced form of twice-exceptional students and therefore gifted students in general. This group of students, if given the proper academic foundation to understand and work with their learning profile, could result in a well-rounded child with both the exceptional potential that can be called upon and the known risks or weaknesses that can be circumnavigated.

The characteristics of twice exceptionality that may be uncovered within this form of research has the distinct possibility of being an assessable variant. If so, this variant would also have the distinct possibility to provide new perceptions 


\section{Gocial Giences \\ by MAP - Multidisciplinary Academic Publishing}

TWICE-EXCEPTIONAL, HALF-NOTICED: THE RECOGNITION ISSUES OF GIFTED STUDENTS WITH LEARNING DISABILITIES

Uma Hamzić and Senad Bećirović

of masking and comorbidity in twice exceptionality. Therefore, the direction of research in terms of replication studies in the fields of Little and Reis (2001; 1995) should incorporate the factor of assessing observed average groups of students and making case studies out of any twice-exceptional students that may be found in those groups.

\section{Conclusion}

The foundation of assessment and intervention of twice-exceptional children has been the identification and definition of the unrecognized students (Crepeau-Hobson \& Bianco, 2010; Baldwin et al., 2015; Finn, 2000; McCoach et al., 2001; Reis et al., 2014). This issue of identification is two-pronged, as it lies both within the lack of definitional understanding outside the specialized community as well as the ever-changing operational definitions of the "academically gifted" and "specific learning disabled" terms (Bećirović \& Polz, 2021; VanderStoep \& Johnston, 2009).

However, these operational definitions and the studies committed to analyzing the data thereof are primarily focused on pre-existing communities with a "gifted" or "disabled" label. As the majority of unrecognized twice-exceptional students suffer from extreme masking (Ottone-Cross et al., 2016; Silverman, 2003), the focus of identification ought to be on what King (2005) defines as the second of three groups; the students that are recorded as average upon surface-level assessment, but are in reality twice-exceptional with near-perfect masks. Furthermore, it is within this specific group of students that the effects of comorbidity may be better understood, as the characteristics of twice-exceptionality are distinct from the individual sides of giftedness and learning disability and require specific research (Ottone-Cross et al., 2016; Reis et al., 2014).

If the body of data we use to identify twice-exceptional students primarily arrives from test groups with pre-assessed labels, researchers will continue to rely on those labels for future assessments. Future research has the potential to further investigate comorbid characteristics within supposedly-average groups of students, in order to determine whether a statistically significant percentage of twice-exceptional students exists. If so, there is also the potential to incorporate case studies of those students, to attempt a compilation of distinguishing features of this specific group.

\section{References}

Ahmetović, E., Bećirović, S., \& Dubravac, V. (2020). Motivation, Anxiety and Students' Performance. 9(2), 27l-289. https://doi.org/10.13187/ ejced.2020.2.271

Assouline, S., Foley Nicpon, M., \& Whiteman, C. (2010). Cognitive and Psychosocial Characteristics of Gifted Students With Written Language Disability. Gifted Child Quarterly, 54(2), 102-115. https:// doi.org/10.1177/0016986209355974

Baldwin, L., Omdal, S. and Pereles, D. (2015). Beyond Stereotypes: Understanding, Recognizing, and Working With Twice-Exceptional Learners. TEACHING Exceptional Children, 47(4), p.216-225

Bećirović, S., \& Akbarov, A. (2016). Talent development through familial environment. International Journal of Social and Educational Innovation (IJSEIrO), 3(5), 7-24.

Bećirović, S., Brdarević-Čeljo, A., \& Dubravac, V., (2018). The Effect of Nationality, Gender, and GPA on the Use of Reading Strategies Among EFL University Students. Sage Open, 1-12. https://doi. org/10.1177/2158244018809286

Bećirović, S., \& Polz, E. (2021). Fostering Giftedness: Challenges and Opportunities. Nova Science Publishers.

Berninger, V. and Dunn, M. (2012). Brain and Behavioral Response to Intervention for Specific Reading, Writing, and Math Disabilities: What Works for Whom?. In: B. Wong and D. Butler, ed., Learning about Learning Disabilities, 4th ed. Cambridge, Massachusetts: Academic Press, pp. 59-88.

Bong, M., \& Skaalvik, E. (2003). Academic Self-Concept and Self-Efficacy: How Different are They Really?. Educational Psychology Review, 15(1), 1-40. https://doi.org/https://doi. org/10.1023/A:1021302408382

Brody, L. (2001). The Talent Search Model for Meeting the Academic Needs of Gifted and Talented Students. Gifted and Talented International, 16(2), pp. 99-102. 


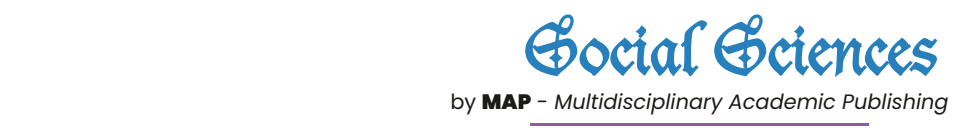

TWICE-EXCEPTIONAL, HALF-NOTICED: THE RECOGNITION ISSUES OF GIFTED STUDENTS WITH LEARNING DISABILITIES

Uma Hamzić and Senad Bećirović

Brody, L., \& Mills, C. (1997). Gifted Children with Learning Disabilities: A Review of the Issues. Journal Of Learning Disabilities, 30(3), pp. 282-296. https://doi.org/10.1177/002221949703000304

Buică-Belciu, C. and Popovici, D. (2014). Being Twice Exceptional: Gifted Students with Learning Disabilities. Procedia - Social and Behavioral Sciences, 127, pp. 519-523.

Coleman, M., Harradine, C., \& King, E. (2005). Meeting the Needs of Students who are Twice Exceptional. TEACHING Exceptional Children, 38(1), 5-7. doi: 10.1177/004005990503800101

Crepeau-Hobson, F., \& Bianco, M. (2010). Identification of gifted students with learning disabilities in a Response-to-Intervention era. Psychology In The Schools, 48(2), 102-109. https://doi. org/10.1002/pits.20528

Cvetković-Lay, J., \& Sekulić-Majurec, A. (1998). Darovito je, što ću s njim? Priručnik za odgoj i obrazovanje darovite djece predškolske dobi. [It's gifted, what am I going to do with it? A handbook for raising and educating gifted preschoolers.] (1st ed.). Alinea.

Feinstein, A. (1970). The pre-therapeutic classification of co-morbidity in chronic disease. Journal of Chronic Diseases, 23(7), pp. 455-468. https://doi.org/10.1016/0021-9681(70)90054-8

Flanagan, D. and Alfonso, V. (2011). Essentials of Specific Learning Disability Identification. 1st ed. Hoboken, New Jersey: John Wiley \& Sons, Inc.

Fletcher, J., Barth, A., \& Stuebing, K. (2011). A Response to Intervention (RTI); Approach to SLD Identification. In D. Flanagan \& V. Alfonso, Essentials of Specific Learning Disability Identification (1st ed. pp. 115-144). John Wiley \& Sons, Inc.

Gallagher, J. (2004). Public policy in gifted education (1st ed.). Thousand Oaks, CA: Corwin Press.

G. Weiss, L., H. Saklofske, D., A. Holdnack, J. and Prifitera, A. (2016). WISC-V Assessment and Interpretation. 1st ed. San Diego, California: Academic Press, pp. 237-268.
Gojkov, G. (1999). Rana identifikacija darovitosti [Early identification of giftedness]. Viša Škola Za Obrazovanje Vaspitača [Higher School for Teacher Education], 5(1).

Individuals with Disabilities Education Act, 20 U.S.C. § 1401 (2004).

Jones, V., \& Jones, L. (1995). Comprehensive classroom management. Allyn \& Bacon.

Hannah, C., \& Shore, B. (2008). Twice-Exceptional Students' Use of Metacognitive Skills on a Comprehension Monitoring Task. Gifted Child Quarterly, 52(1), pp. 3-18. https://doi. org/10.1177/0016986207311156

Kaufman, A. S. (2008). Neuropsychology and specific learning disabilities: Lessons from the past as a guide to present controversies and future practice. In E. Fletcher-Janzen \& C. R. Reynolds, Neuropsychological perspectives on learning disabilities in the era of RTI: Recommendations for diagnosis and intervention (pp. 1-13). Hoboken, NJ, US: John Wiley \& Sons.

Little, C. (2001). A Closer Look at Gifted Children with Disabilities. Gifted Child Today, 24(3), 4664. https://doi.org/10.4219/gct-2001-537

Lyudmila, P., \& Maria, R. (2014). Gifted children and their Problems. Austrian Journal Of Humanities And Social Sciences, 1(1), pp. 297-301.

Mašić, A., Polz, E., \& Bećirović, S. (2020). The Relationship between Learning Styles, GPA, School Level and Gender. European Researcher, 11(1), 51-60. https://doi.org/10.13187/er.2020.1.51

Matthews, D. and Foster, J. (2005). Being Smart about Gifted Children. 1st ed. Scottsdale, Arizona: Great Potential Press.

McCoach, D., Kehle, T., Bray, M., \& Siegle, D. (2001). Best practices in the identification of gifted students with learning disabilities. Psychology In The Schools, 38(5), 403-411. https://doi.org/10.1002/ pits.1029

Munro, J. (2002). Gifted learning disabled students. Australian Journal Of LearningDisabilities, $7(2)$, 20-30. https://doi.org/10.1080/19404150209546698 


\section{Gocial Geiences \\ by MAP - Multidisciplinary Academic Publishing \\ TWICE-EXCEPTIONAL, HALF-NOTICED: THE RECOGNITION ISSUES OF GIFTED STUDENTS WITH LEARNING DISABILITIES \\ Uma Hamzić and Senad Bećirović}

Ottone-Cross, K., Dulong-Langley, S., Root, M., Gelbar, N., Bray, M., Luria, S., Choi, D., Kaufman, J., Courville, T. and Pan, X. (2016). Beyond the Mask: Analysis of Error Patterns on the KTEA-3 for Students With Giftedness and Learning Disabilities. Journal of Psychoeducational Assessment, 35(1-2), pp. 74-93.

Ottone-Cross, K., Gelbar, N., Dulong-Langley, S., Root, M., Avitia, M., Bray, M., Courville, T. and Pan, X. (2018). Gifted and learning-disabled: A study of strengths and weaknesses in higher-order processing. International Journal of School \& Educational Psychology, 7(1), pp. 173-181.

Pretti-Frontczak, K. and Bricker, D. (2000). Enhancing the Quality of Individualized Education Plan (IEP) Goals and Objectives. Journal of Early Intervention, 23(2), pp. 92-105.

Reis, S., Baum, S. and Burke, E. (2014). An Operational Definition of Twice-Exceptional Learners. Gifted Child Quarterly, 58(3), pp. 217-230.

Reis, S., Neu, T., \& McGuire, J. (1997). Case Studies of High-Ability Students with Learning Disabilities Who Have Achieved. Exceptional Children, 63(4), pp. 463-479. https://doi. org/10.1177/001440299706300403

Roedell, W. (1984). Vulnerabilities of highly gifted children. Roeper Review, 6(3), 127-130. doi: $10.1080 / 02783198409552782$

Silver, L. (1989). Learning disabilities: Introduction. Journal of The American Academy of Child And Adolescent Psych, 28(1), pp. 309-313.

Silverman, L. (2003). Gifted children with learning disabilities. In N. Colan-gelo \& G. Davis, Handbook on Gifted Education (3rd ed., pp. 533543). Allyn \& Bacon.

Swanson, H., Harris, K., \& Graham, S. (2021). Handbook of Learning Disabilities (2nd ed., pp. 3056). Guilford Press.

VanderStoep, S. and Johnston, D. (2009). Research Methods for Everyday Life. 1st ed. San Francisco, California: John Wiley \& Sons, Inc.

Wang, C. and Neihart, M. (2015). Academic Self-Concept and Academic Self-Efficacy: Self-Beliefs Enable Academic Achievement of Twice-Exceptional Students. Roeper Review, 37(2), pp. 63-73.
Williams King, E. (2005). Addressing the Social and Emotional Needs of Twice-Exceptional Students. TEACHING Exceptional Children, 38(1), pp. 1620.

Winner, E. (1996). Gifted Children: Myths And Realities (lst ed.). Basic Books.

Wood, S., \& Estrada-Hernández, N. (2009). Psychosocial Characteristics of Twice-exceptional Individuals: Implications for Rehabilitation Practice. Journal Of Applied Rehabilitation Counseling, 40(3), 11-18. https://doi.org/10.1891/0047-2220.40.3.11

Woolfolk, A. (2016). Educational Psychology (13th ed.). Pearson Education Limited. 